\title{
Correlations with Point Mutations and Severity of Hemolitic Anemias: The Example of Hereditary Persistence of Fetal Hemoglobin with Sickle Cell Anemia and Beta Thalassemia
}

\author{
Anderson Ferreira da Cunha ${ }^{1}$, Iran Malavazi ${ }^{1}$, \\ Karen Simone Romanello ${ }^{1}$ and Cintia do Couto Mascarenhas ${ }^{2}$ \\ ${ }^{1}$ Departamento de Genética e Evolução, \\ Centro de Ciências Biológicas e da Saúde, \\ Universidade Federal de São Carlos, \\ ${ }^{2}$ Centro de Hematologia e Hemoterapia, \\ Universidade Estadual de Campinas,
} Brazil

\section{Introduction}

Hemolytic anemias are a group of diseases characterized by a reduction in red blood cells (RBC) life span mainly caused by a deregulation in the hemoglobin formation. Among these diseases, Sickle Cell Disease (SCD) and Beta Thalassemia ( $\beta$ Thal) are the most common disorders involved in the premature destruction of RBC. Understanding the molecular mechanisms involved in the outcome of these diseases as well as the metabolic pathways surrounding its onset constitutes a very useful approach to target treatment strategies for such diseases. In this chapter we will discuss the state-of-the-art aspects about this theme highlighting the importance of several point mutations in hemolytic anemia using $\beta$ thalassemia and sickle cell disease as examples. In addition, the molecular aspects involved in the Hereditary Persistence of Fetal Hemoglobin (HPFH), also an important disorder caused by point mutations and deletions, and its association with the severity of $\beta$ Thal and SCD will be also discussed. In this context lies the manifestation of better prognostic to patients having an increase in fetal hemoglobin and SCD or $\beta$ Thal concomitantly. Therefore a parallel discussion towards the advances currently described in the literature and associations of gene expression and different drugs that increase the production of fetal hemoglobin $(\mathrm{HbF})$ are pointed out as a mechanism to improve the quality of life of SCD and $\beta$ Thal patients.

\section{The erythroid cell}

Erythroid proliferation is a precisely regulated process, in which hematopoietic stem cells (HSCs) differentiate into lineage-restricted erythroid progenitors through a process called 
erythropoiesis. While in adult humans the process occurs basically in the bone marrow (BM), the primitive hematopoiesis occurs initially in the yolk sac (YS). (Fig. 01) The regulation of cellular proliferation, survival and differentiation is a strictly regulated process in all the producing cells and are stimulated by extracellular signaling molecules, particularly erythropoietin (EPO), a hormone synthesized by the kidney. This hormone functionally activates its receptor called EPOR on the surface of red blood cells (RBCs) precursor cells in the BM. The first cell line formed after this stimulus is known as Burst Forming Unit-Erythroid (BFU-E) (Hoffman et al. 2008).

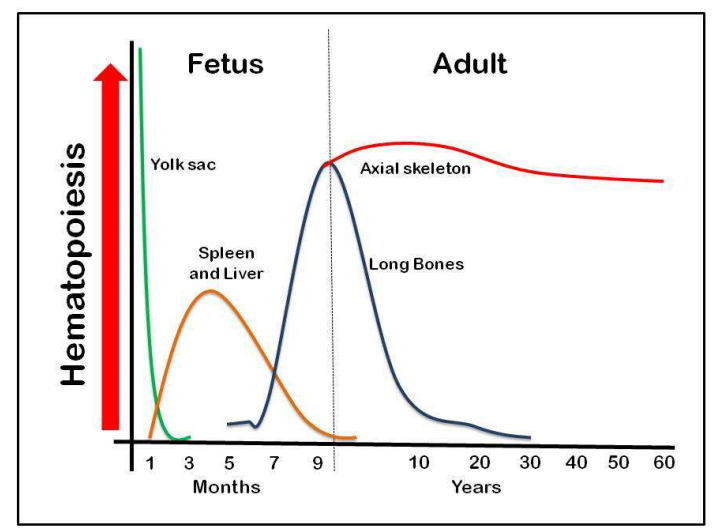

Fig. 1. Sites of hematopoesis during the human development. During the very first weeks of human development the hematopoiesis occurs in the yolk sac. After the first month, the hematopoietic site is switched to spleen and liver and after the seventh month all the hematopoiesis occurs in long bones. Following the birth and during the adult life the hematopoesis site is in the axial skeleton.

After the EPO stimulus, cells undergo several modifications that lead to the formation of RBCs. The first step occurs when the Burst forming unit erythroid cells (BFU-E) originates the colony-forming units erythroid (CFU-E), which differentiates to the first morphologically identifiable stage of the erythroid cells, the proerythroblasts. Successive modifications lead the cell to several transforming processes generating the basophilics erythroblasts, polychromatophilics erythroblasts, orthochromics erythroblasts. At this stage, the nucleus becomes picnotic and is extruded of the cell forming the reticulocyte. This cell presents a biconcave shape and contains residual remaining RNA. Reticulocytes are released into the blood and develop into mature erythrocytes within about two days (Fig. 02) (Hoffman et al. 2008; Tsiftsoglou et al. 2009).

Under normal conditions, erythrocytes life span is about 120 days. After this time, the erythrocytes undergo several morphological changes, specially caused by reduction in its metabolic activity and the hemoglobin content oxidation (Ghaffari 2008). These cell alterations are ultimately recognized by mononuclear phagocyte system (MPS). The cells are then removed from bloodstream in that the majority of the cell components are recycled and used in the production of new cells. The MPS consists of phagocytic cells (macrophages and monocytes) residents in the liver and spleen which are the major organs responsible for 
RBCs removal. An increase in RBCs destruction independent from the etiology results in a clinical disorder generally called anemia. This unbalanced destruction of the RBC population is the most important feature found in several hemolytic diseases like sickle cell disease and $\beta$ Thal that will be further discussed in detail later on in this chapter (Telen et al. 1999; Hoffman et al. 2008).

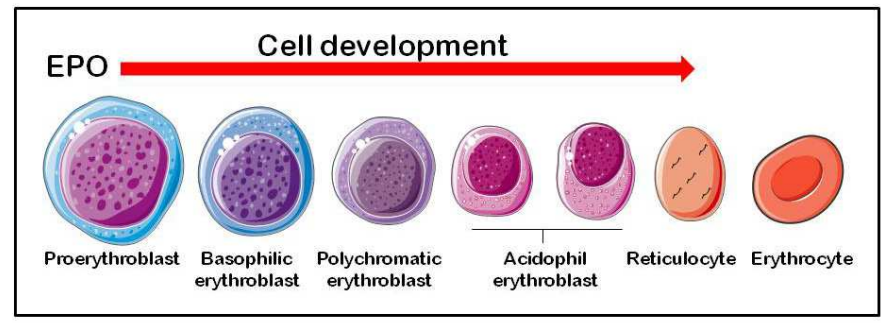

Fig. 2. Morphological changes during erythropoiesis in humans - After EPO stimulus the erythroid cell undergo several morphological changes that lead to the formation of mature erythrocytes. For details see the text. Figure was produced using Servier Medical Art, http:// www.servier.co.uk/medical-art-gallery/SlideKit.asp?kit=18.

\section{The hemoglobin}

The main function of erythrocytes is the transport of oxygen from lung to peripheral tissues and carbon dioxide from them to the lung. This function is performed by the hemoglobin $(\mathrm{Hb})$ molecule, a protein tetramer which comprises $95 \%$ of the whole protein content in RBC.

Hemoglobin synthesis requires the coordinated production of different globin proteins combined with a non-protein heme group as a prosthetic group. Heme molecule consists of an iron (Fe) ion held in a heterocyclic ring, known as a porphyrin. The protoporphyrin present in erithrocytes is the protoporphyrin IX which is a complex structure of a tetrapyrole structure. This molecule comprises four pyrole rings having eight sites for side chain groups substituents at its periphery. The protoporphyrin IX can then be described as 1,3,5,8 methyl; 2,4 vinyl; 6,7 propionic acid-porphiryn. The designation of protoporphiryn IX refers to the fact that from the 15 possible isomers of protoporphyrin, the ninith one that Hans Fischer (the pioneer in the chemical foundations of proptoprphyrin molecules) synthetized was exactly the same naturally occurring in the heme molecule. Therefore, the IX isomer is the only one found in nature (Greer et al. 2008).

Iron is the site of oxygen binding when it is in the ferrous $\left(\mathrm{Fe}^{2+}\right)$ oxidation state. The hemoglobin can be saturated with oxygen molecules (oxyhemoglobin), or desaturated without oxygen (deoxyhemoglobin). Two distinct globin chains are combined to form hemoglobin, the alpha and non-alpha (Fig. 3a).

The alpha cluster located at chromosome 16 is responsible for the production of $\zeta$ and $\alpha$ globin. On the other hand, the production of non-alpha chains occurs in the $\beta$ cluster located at chromosome 11. In this latter cluster the $\varepsilon, \gamma, \delta$ and $\beta$ globin are produced. (Fig. 3b) (Tang et al. 2008). 


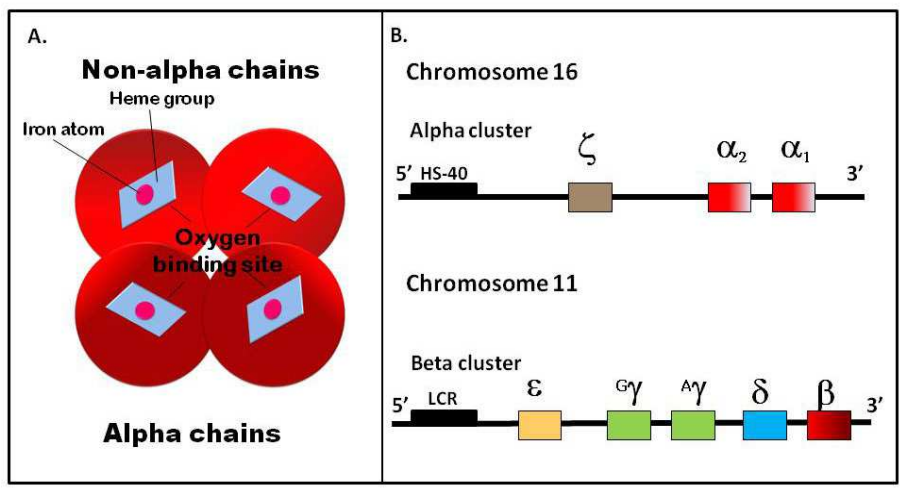

Fig. 3. Formation of hemoglobin during the human development - (A) Schematic representation of hemoglobin showing its molecules. (B) The hemoglobin is composed by the combination of two alpha and two non-alpha chains. The proteins are produced by the expression of several genes located in the $\alpha$ and $\beta$ cluster at Chromosome 16 and 11 respectively.

The ontogeny of globin synthesis during development is complex and dynamic having different proteins being produced by different clusters. During the first weeks of embryogenesis the predominant globin chain synthetized by $\alpha$ cluster is the $\zeta$ globin. After this time, the globin chain produced by the $\alpha$ cluster is always represented by the $\alpha$ globin. However, the $\beta$ cluster can produce several different globin proteins as shown in Fig. 3 . During the fetal period, the non-alpha globins produced are the $\varepsilon$ (2 - 6 weeks) and $\gamma$ (after the $6^{\text {th }}$ week). After the birth, the $\gamma$ gene is silenced and the transcription of the $\beta$ and $\delta$ gene starts indefinitely. The most abundant globin occurring after the birth expressed by $\beta$ cluster is the $\beta$ globin that represents about $98 \%$ of non-alpha chains found in the mature erythrocyte The control mechanisms of the transcription modulation of globin genes are not completely understood. Some studies showed that the Locus Control Region (LCR) present in $\beta$ cluster and the HS40 (Hypersensitive site 40) region in $\alpha$ cluster bend on the promoter of each gene enhancing its transcription. When these regions fold up in the subsequent promoter, the silencing of the preceding gene occurs with the consequent activation of transcription in the subsequent gene. The transcription factors involved in LCR and HS40 movements remains unclear but some relevant aspects of this regulation module will be discussed later in this section. The combination of two $\alpha$ chains and two non- $\alpha$ chains produces a complete hemoglobin molecule (Palstra et al. 2003; Hoffman et al. 2008).

In humans, as for the expression of globin genes, the production of $\mathrm{Hb}$ is also ontogenetically regulated. Therefore, different types of hemoglobin are produced according to the developmental cell stage (i. e. embryonic, fetal and adult). Embryonic Hbs are produced early during hematopoiesis when erythropoiesis is predominantly in the yolk sac. The first hemoglobin produced in embryo is the gower 1 formed by the combination of two $\zeta$ globins and two $\varepsilon$ globins $\left(\zeta_{2} \varepsilon_{2}\right)$. The hemoglobin Gower 2 is then formed by the combination of two $\alpha$ and two $\varepsilon$ globin $\left(\alpha_{2} \varepsilon_{2}\right)$. The Portland hemoglobin is the third class of globins produced in embryos as a result of the association of two $\zeta$ and two $\gamma$ globin $\left(\zeta_{2} \gamma_{2}\right)$. During the fetal period the first hemoglobin switching takes place when the $\alpha$ globin is 
combined with $\gamma$ globin $\left(\alpha_{2} \gamma_{2}\right)$, producing the fetal hemoglobin $(\mathrm{HbF})$. In this period, the hemoglobin is synthesized in the liver. During the first six weeks after the birth, occurs the second hemoglobin switching. At this stage the $\gamma$ globin synthesis is drastically decreased and the production of $\beta$ globin starts. The combination of $\alpha$ and the newly $\beta$ globin produced results in the major hemoglobin counterpart found during the adult life which is called $\mathrm{HbA1}\left(\alpha_{2} \beta_{2}\right)$. There is also another adult normal hemoglobin formed by the combination of $\alpha$ and $\delta$ globins the $\operatorname{HbA} 2\left(\alpha_{2} \delta_{2}\right)$, that represents $1.5-3.5 \%$. The Fig. 4 shows the ontogenetic production of hemoglobin depicting the sites of production and the time of development where the different globin chains peaks in concentration (Fig. 04) (Stamatoyannopoulos 2005).

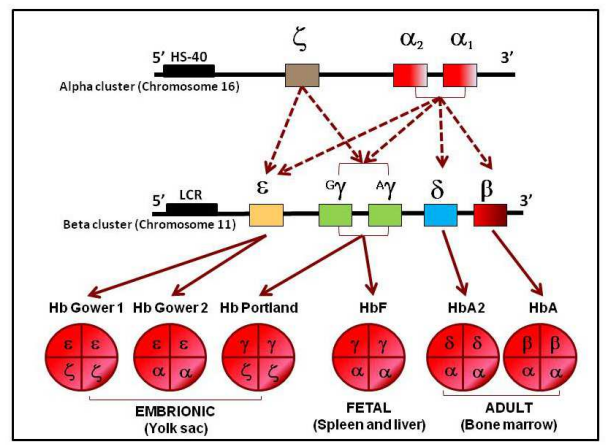

Fig. 4. The production of different types of hemoglobins during human development During human development different types of hemoglobin are produced. In the embryonic phase de $\mathrm{Hb}$ Gower 1 and 2 and also $\mathrm{Hb}$ Portland are produced. In the fetal phase the combination of $\gamma$ and $\alpha$ proteins produced the $\mathrm{HbF}$. After the birth, two hemoglobins are produced, the $\mathrm{HbA} 2$ that represents about $1.5-3.5 \%$ of total hemoglobin in adult blood and the $\mathrm{HbA}$ that represents $95-98 \%$ of hemoglobin.

\subsection{The genetic regulation of globin genes}

As discussed earlier, the genetic control of hemoglobin production is not completely understood, however several studies showed that globin genes can be expressed and repressed upon the regulation of several transcription factor that can interact with the globin gene promoters. As mentioned before, in the $\beta$ globin cluster, the LCR can interact with the different globin genes in this cluster forming the different types of hemoglobin. This region is comprised of hypersensitive sites, which are DNA stretches with marked sensitivity to in vitro DNAse treatment. The precise function of LCR is not still completely clear. Several studies have shown that it acts as a "super-enhancer" DNA sequence that is thought to interact with each globin gene in the cluster by the interactions with several transcription factors. There are some other important regions surrounding the globin genes that are probably involved in its own transcription. One of these regions is a sequence spanning -80 and -120 bp upstream the start codon called the TATA and CAT box, respectively. These regulatory regions bind to and interacts with RNA polymerase in the beginning of globin gene transcription. Also of seminal importance is the region located at 3 ' region of the transcription start site, called as the GATA binding sequence. In such region, a transcription 
factors called GATA, a zinc-finger family of transcription factors (GATA 1-6), interacts with DNA and can both activate and repress target genes involved in erythroid development (Strauss et al. 1992; Strauss et al. 1992; Cao et al. 2011).

Specially in $\alpha$ - and $\beta$-globin loci, several binding sites for this family are found, suggesting an important role of these proteins in the regulation of these genes. The same motif is also found in the promoters of several genes that are also regulated during the erythroid development. GATA1 is the main member of these family involved in erythroid cell maturation in vivo. Its expression is essential for the formation of erythroid definitive lineage and several studies showed that erythroid Gata1-null cells can not mature beyond the proerythroblast stage. GATA1 seems to be also involved in the switching of the fetal to adult hemoglobin. Mutation in GATA1 gene has been described as involved in congenital erythropoietic porphyria and elevated levels of $\mathrm{HbF}$. However the exact mechanism that links this gene to the elevation of $\gamma$ globin is still not completely clear (Weiss et al. 1994; Blobel et al. 1995; Weiss et al. 1995; Blobel et al. 1996; Weiss et al. 1997; Blobel et al. 1998).

As mentioned before, these DNA sequences are well recognized as sites of bona fide globin gene expression regulation. The presence of mutations in such regions leads to a deregulation in the expression of globin genes causing either interruption or a decreased expression of such genes.

Besides this, regulation involving the gene transcription licensing, several other genetic factors have been described up to now as involved in the globin gene regulation. The $B C L 11 A$ gene, as the GATA family is a zinc-finger protein, firstly identified as a potentially important factor in globin regulation and as a master regulator in the switch of the fetal to adult hemoglobin in humans. This gene is under the transcriptional regulation of a transcription factor known as KLF1 (Kruppel-like factor). KLF1 binds to a CACCC motif and this association is also strictly correlated to $\gamma$ to $\beta$-globin gene switching. Mutation in this binding motif is associated with human $\beta$ Thal and Hereditary Persistence of Fetal Hemoglobin that will be discussed later on (Sankaran et al. 2008; Xu et al. 2010).

Another important set of genes involved in the erythroid terminal differentiation is SOX6 and ALAS2. SOX6 is a transcription factor expressed in several human tissues. Specifically in erythroid cells, it has been reported that SOX6 expression is crucial to promote erythroid final maturation, since an increased number of nucleated and immature red cells are observed in blood stream when this gene is deleted in mouse. ALAS2 is the enzyme catalysing the first and regulatory step of heme synthesis. Its expression is restricted to erythroid precursor cells. Therefore, reported mutations in ALAS2 have been linked to ineffective erythropoiesis and associated to X-linked sideroblastic anaemia (Ducamp et al. 2010; Wilber et al. 2011).

\subsection{Hemolytic anemia}

Despite many studies focusing on the understanding of the complete regulation of hemoglobin formation highlighted in the previous section, many aspects of this regulation are still to be addressed. Deregulation of hemoglobin formation is involved in the reduction of red blood cells leading to a important disorder called hemolytic anemia After the normal life span of about 120 days, the red blood cells need to be removed from the circulation. 
Spleen and liver are the most important tissues responsible for the destruction and recycling of red blood cells components. In normal conditions, the destruction of these cells is balanced with their production in the bone marrow and the number of circulating red blood cells is physiologically maintained (Hoffman et al. 2008).

An unbalanced rate of destruction and production of RBC can increase or reduce the population of circulating cells. The increase of these cells is denominated policytemia and this clinical condition is present in several proliferative disorders. On the other hand, the reduction of RBC number consists of anemia and can be developed by several reasons, including some erythroid diseases including sickle cell disease and $\beta$ Thal. In these cases, the anemia is called hemolytic because the established condition is caused by an increase in hemolysis of the RBC.

The anemia is most often diagnosed through hematological tests in which a decrease in hemoglobin concentration and in RBC cell count are detected. Despite the laboratory diagnosis, the clinical history and physical examination can provide important clues about the presence of hemolysis and its underlying cause. The patient may complain of dyspnea or fatigue (caused by anemia). Dark urine and, occasionally, back pain may be reported by patients with intravascular hemolysis. The skin may appear jaundiced or pale. A resting tachycardia with a flow murmur may be present if the anemia is pronounced. Leg ulcers occur in some chronic hemolytic states, such as sickle cell anemia. Hepatosplenomegaly suggest an abnormal RBC destruction caused by accentuated hemolysis (Hoffman et al. 2008).

Besides the anemia, another important laboratory feature that indicates an accelerated hemolysis is reticulocytosis which is characterized by an increase in reticulocytes in peripheral blood (see Fig. 02). This increased prevalence of reticulocytes is the physiological bone marrow response attempting to the restoration (in number) of the cells loosen. In the absence of concomitant bone marrow disease, a brisk reticulocytosis should be observed within three to five days after a decline in hemoglobin. After this period, in a normal condition the RBCs production is compensated, leading to a normal and stable hemoglobin concentration.

In contrast, in the hemolytic anemia, although a marked reticulocytosis is observed after the RBCs destruction, the bone marrow is not able in compensate the formation of normal RBCs. The main cause for this fail is the fact that the primary event affecting RBCs involves an absence, reduction or malformation of hemoglobin. In the next sections we will discuss two important erythroid diseases that culminate to chronic hemolytic anemias whose main genetic alteration is accounted by a point mutation: the sickle cell disease and $\beta$ Thal. We will also discuss another important disorder generated by a point mutation that importantly has beneficial effects on the described diseases: the Hereditary Persistence of Fetal Hemoglobin.

\section{Sickle Cell Disease}

Sickle cell disease (SCD) is a worldwide health problem and one of the most common inherited disorders firstly reported in America by James Herrick in 1910. In 1949, Linus Pauling and colleagues demonstrated that sickle hemoglobin had a different migration compared to the normal hemoglobin in an electrophoretic field and recognized that this disease must be associated with a variant hemoglobin molecule (Pauling et al. 1949) The 
genetic alteration that leads to this autosomal recessive inherited disorder was described in 1957 by Ingram and colleagues, as a missense mutation $(\mathrm{A}-\mathrm{T})$ that introduces a substitution of a glutamic acid, a polar negatively charged aminoacid (in hemoglobin A) to valine, non polar aminoacid (in hemoglobin S) at position 6 of the globin $\beta$-chain causing an impairment in hemoglobin structure and function (Ingram 1957).

Since SCD has a Mendelian segregation, individuals can be homozygous or heterozygous. The genetic diagnostic of the disease can identify an important prognostic in the homozygous for the sickle gene (SS) once their erythrocytes contain at least $90 \%$ hemoglobin S. Those who are heterozygous (AS) have sickle cell trait and their erythrocytes contain both hemoglobin A (about 50-60\%) and hemoglobin S (about 30-40\%). Sickle cell trait is a clinical state that is clinically benign except under conditions of severe acidosis or low partial oxygen pressure (Pace 2007).

An important piece of information about the prognostic of patients carrying SCD was described by several studies that identified single nucleotide polymorphism (SNPs) in the $\beta$ globin locus. These haplotypes were firstly defined in African population and identified in different regions that could be linked to different gene mutations. These regions are Benin, Senegal, Central African Republic (Bantu) and Cameroon. Another important haplotype was described in Saudi Arabia and India. The identification of these haplotypes was possible by digesting the $\beta$ globin locus with several restriction enzymes. The pattern of each haplotype can be seen in Fig. 05. The occurrence of these is very broad worldwide but mainly in America, what is a direct consequence of the forced migration of Africans to America as slavers. The identification of these haplotypes is a very important tool for evaluating the prognostic of the disease, since several studies showed that different haplotypes accounts for different clinical evolution of the disease. For example, the Bantu haplotype is associated with a worse prognostic than others in the majority of cases (Pagnier et al. 1984; Nagel et al. 1985; Pace 2007).

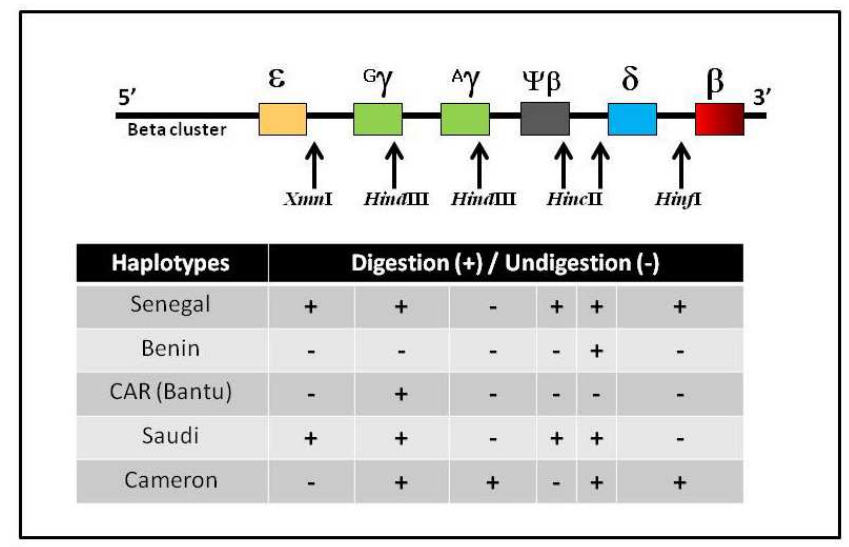

Fig. 5. Different haplotypes found in association with Sickle Cell Disease (SCD). Using different restriction enzymes, several haplotypes could be found and associated with the better or worse prognostic in SCD. 
A significant association between endemic regions of malaria infestation and spontaneous $\beta$ globin mutation were described by Carlson et al based on natural selection, since people with sickle cell trait are more resistant to malaria than people with two normal $\beta$ globin genes. This is a very elegant example of a point mutation as a factor eliciting a direct consequence in the adaptation of a pathogen to the host (Carlson et al. 1994).

Under oxygenated conditions both hemoglobin $\mathrm{S}$ and hemoglobin A have similar function. However, when hemoglobin is in the deoxygenated state, cells carrying hemoglobin $S$ become deformed and acquire sickle shape. The alterations observed in the HbS cell morphology is due the appearance of a new hydrophobic site in hemoglobin $S$ that interact with another HbS protein leading to a formation of a long and multi-stranded fibers. This leads to several alterations such as red cell membrane damage, chronic hemolysis, altered interactions between sickle red blood cells and vascular endothelial cells, and inflammatory responses from such interactions (Fig. 6) (Pace 2007; Hoffman et al. 2008).

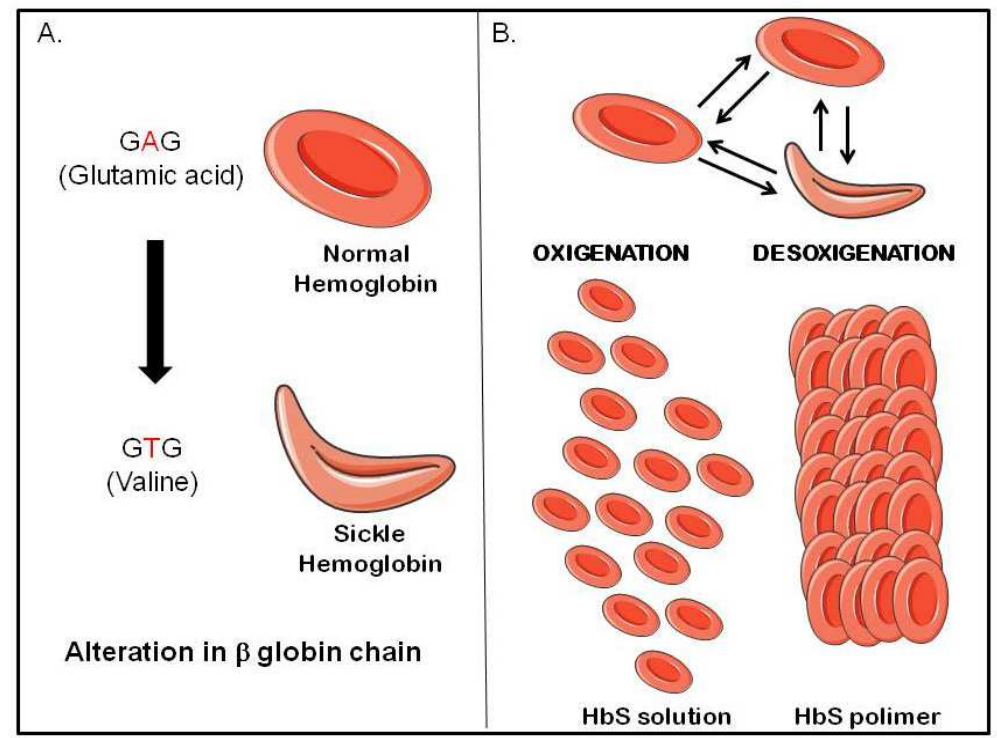

Fig. 6. Pathophysiology of sickle cell disease - The single point mutation (GAG - GTG) at $\beta$ globin gene leads to a formation of sickle hemoglobin $(\mathrm{HbS})$. This alteration is caused by a change of a Glutamic acid by a Valine at position six of the protein (A). Under oxygenation state the $\mathrm{HbS}$ have the same function than a normal $\mathrm{Hb}$, however at absence of oxygen these cells interact with other $\mathrm{HbS}$ cells forming a $\mathrm{HbS}$ polimer that adhere to blood vessels leading to several alterations observed in this disease (B). Figure was produced using Servier Medical Art, http://www.servier.co.uk/medical-art-gallery/SlideKit.asp?kit=18.

Another hallmark event caused by the alteration in red blood cells shape is the sequestration of blood cells in the spleen and liver, resulting in a preeminent hepatosplenomegaly typically observed in SCD patients. In a first moment, the bone marrow increases the production of reticulocytes. As a consequence, the level of these cells that normally represents about $1 \%$ can be as high as $10 \%$ under these conditions. With the continued 
destruction of red blood cells associated to the hemolysis in the bloodstream, a great decrease in the number of circulating red blood cells can be observed culminating with an anemic condition (Pace 2007).

The primary event involved in the pathophysiology of SCD is the vaso-occlusion outcome that can promote strokes, resulting in tissues infarctation, painful episodes, acute chest syndromes and thrombosis of cerebral vessels (Shapiro et al. 1995).

Several studies support the idea that exists a genetic predisposition to stroke associated with the different $\beta$ globin haplotypes (Powars et al. 1994). The increase of sequenced data from Human Genome Project, associated with the improvement of bioinformatics tools and highthroughput genotyping platforms and sequencing, called as the "genomic revolution", accelerated the identification and association of SNPs with several diseases, including SCD. The association of this information is a powerful tool in the discovery of new associations between novel haplotypes and SCD prognostic (Pace 2007).

Red cell transfusion and therapy with the use of Hydroxyurea (HU) are methods used to prevent the complications of SCD. The use of HU, a chemotherapy agent largely used in the treatment of mieloproliferative disease, in the SCD treatment was first demonstrated by the Multicenter Study of Hydroxyurea in Sickle Cell Anemia (MSH). This study showed that by the use of this pharmacological agent, the rate of painful episodes and the need for transfusions were decreased. Another important finding is the correlation of HU treatment and the increase of $\mathrm{HbF}$. This point will be discussed later on in this chapter (Steinberg et al. 2003).

The only curative therapy for SCD is the hematopoietic stem cell transplantation, but this therapy has some important complications such as acute and late toxicities that need to be considered before its use. The evolution of the transplantation method with the possibility of alternate use of stem cell source such as cord blood could be improve the cure of this disease for a large number of individuals (Pace 2007).

\section{Thalassemia}

The thalassemia term was first used for anemia often found in Italian people and the Greek shores and nearby islands. Today the term is used to refer to inherited defects in the biosynthesis of globin chains (Hoffman et al. 2008; Cao et al. 2010).

The thalassemias are a group of inherited disorders characterized by alterations in the synthesis of one or more globin chain subunits in the hemoglobin tetramer. The clinical features associated with thalassemia arise due to an imbalanced production of globin, which leads to ineffective erythropoiesis and consequently hemolytic anemia. Thalassemic individuals may be asymptomatic or the clinical manifestations can vary from a hypochromic and microcytic anemia to changes that become incompatible with life.

These differences in clinical manifestations arise from defects of varying severity in primary biosynthesis and modulation inherited factors, such as increased synthesis of fetal globin subunits. In more severe forms of disease, iron overload can occurs as a consequence of either blood transfusions (which is used as palliative treatment) or alloimmunization and blood-borne infections (Thein 1998). 
Thalassemias represent one of the most common group of genetic disorders known, thus constituting a public health problem. Molecular analysis of these disorders, mainly the study of molecular changes underlying the thalassemia syndromes, has led to fundamental advances in understanding the structure and function of eukaryotic genes. The classification, pathophysiology and genetic basis of this disease were used as a model to understand the production and the formation of hemoglobin and their main function as carriers of oxygen molecules bounded to heme group.

The thalassemia syndromes are named according to the globin chain whose synthesis is affected. Therefore, the $\alpha$-globin chains are absent or reduced in patients with $\alpha$-thalassemia, and $\beta$-globin chain production is altered in patients with $\beta$ Thal, the $\delta$ and $\beta$ chains globin production are altered in patients with $\delta \beta$-thalassemia among others. This nomenclature is also important to subdivide the patients depending on the level of production of each globin chain, which can be reduced (eg $\alpha$ or $\beta^{+}$- thalassemia) or absent (eg $\alpha$ or $\beta^{0}$ - thalassemia). In this topic we will focus on $\beta$ Thal (Hoffman et al. 2008).

Heterozygote individuals for $\beta$ thalassemia, called thalassemia trait, may develop anemia, yet can have a normal life. Whereas individuals who are homozygous can be classified into different groups: (i) thalassemia intermedia - in which individuals has moderate anemia due to reduced production of $\beta$-globin, and (ii) thalassemia major or Cooley's anemia characterized by severe reduction or absence of production of $\beta$-globin. These patients with $\beta$ Thal major are dependent on periodic blood transfusions and as a consequence of this procedure, they may have a significant accumulation of iron in multiple organs and tissues. Thus, the treatment with iron chelating drugs, such as deferoxamine is mandatory, and can also cause death. Currently the only curative treatment available for these patients is bone marrow transplantation (Wheatherall et al. 2001).

\subsection{Beta talassemia}

Strikingly, more than two hundred mutations have been described to date as associated with this disease. Total gene deletion which could account for the total absence of $\beta$ chain synthesis is rarely observed in $\beta$ Thal. The majority of the mutations found so far are mainly either single nucleotide substitutions and deletions or insertions of nucleotides on frameshift leading. Although there are several mutations described, only about nine of them usually represent more than $90 \%$ of cases of $\beta$ Thal in a particular ethnic group or region. Mutations can be divided into those that affect the transcription of mRNA (mutation on the promoter region and termination codon), those affecting mRNA processing (splicing junctions mutations, new signs of splicing, cleavage and recombination deficient) and those affecting the translation (Cao et al. 2011).

As we discussed before, different types and amounts of human hemoglobin are determined by the selective expression of specific genes encoding each globin chain. Also encoded within the genes are the signals that permit the enzymatic machinery within the nucleus to excise precisely the introns from the mRNA precursor and bring together the exons to form a mature mRNA. Many mutations are related to transcription of the $\beta$ globin genes. These mutations alter the promoter region upstream of the $\beta$-globin mRNA coding sequence. In addition, other mutations can alter the sequence used for signaling the addition of the tail poly (A) of mRNA upstream of the $\beta$ globin mRNA coding sequence. These events ultimately affects the mRNA 
synthesis resulting in abnormal division and polyadenylation of mRNA precursor leading to reduction of mature mRNA (Table 1 and fig. 7) (Hoffman et al. 2008).

\begin{tabular}{|c|c|}
\hline DEFECT & TYPE OF THALASSEMIA \\
\hline \multicolumn{2}{|l|}{ mRNA non-functional } \\
\hline $\begin{array}{l}\text { 1. Premature Finish Codon } \\
\text { a. } \quad \mathrm{CD} 15 \mathrm{G} \rightarrow \mathrm{A}, \\
\text { b. } \quad \mathrm{CD} 17 \mathrm{~A} \rightarrow \mathrm{T}, \\
\text { c. } \quad \mathrm{CD} 35 \mathrm{C} \rightarrow \mathrm{A}, \\
\text { d. } \quad \mathrm{CD} 39 \mathrm{C} \rightarrow \mathrm{T}, \\
\text { e. } \quad \mathrm{CD} 43 \mathrm{G} \rightarrow \mathrm{T}, \\
\text { f. } \quad \mathrm{CD} 121 \mathrm{~A} \rightarrow \mathrm{T}\end{array}$ & $\beta^{0}$ \\
\hline $\begin{array}{l}\text { 2. Short Deletion Shift Base (frameshift) } \\
\text { a. CD } 5-C T, \\
\text { b. CD } 6-C \text {, } \\
\text { c. CD 8/9+G, } \\
\text { d. CD 16-C, } \\
\text { e. CD } 35-C \text {, } \\
\text { f. CD 41/42-TTCT, } \\
\text { g. CD 76-C, } \\
\text { h. CD 109/110 1nt del }\end{array}$ & $\beta^{0}$ \\
\hline $\begin{array}{l}\text { 3. Mutation of the Start Codon ATG } \\
\text { a. ATG } \rightarrow \text { AGG, } \\
\text { b. ATG } \rightarrow \text { ACG }\end{array}$ & $\beta^{0}$ \\
\hline \multicolumn{2}{|l|}{ Abnormal Processing RNA } \\
\hline $\begin{array}{l}\text { 1. Mutations Inside Introns } \\
\text { a. IVS-1 nt } 110 \mathrm{G} \rightarrow \mathrm{A}, \\
\text { b. IVS-2 nt } 705 \mathrm{~T} \rightarrow \mathrm{G}, \\
\text { c. IVS-2 } 745 \mathrm{C} \rightarrow \mathrm{G} \\
\text { d. IVS-1 nt } 116 \mathrm{~T} \rightarrow \mathrm{G}, \\
\text { e. IVS-2 nt } 654 \mathrm{C} \rightarrow \mathrm{T}\end{array}$ & $\beta^{+}$ \\
\hline $\begin{array}{ll}\text { 2. } & \text { Activation of Cryptic Sites of Splicing } \\
\text { a. } & \text { CD } 19 \mathrm{~A} \rightarrow \mathrm{G}, \\
\text { b. } & \mathrm{CD} 26 \mathrm{G} \rightarrow \mathrm{A}, \\
\text { c. } & \mathrm{CD} 27 \mathrm{C} \rightarrow \mathrm{T}\end{array}$ & $\beta^{+*}$ \\
\hline $\begin{array}{ll}\text { 3. Mutations in exon-intron limits } \\
\text { a. IVS-1 nt } 1 \mathrm{G} \rightarrow \mathrm{A}, \\
\text { b. IVS-1 nt } 1 \mathrm{G} \rightarrow \mathrm{T}, \\
\text { c. IVS-1 nt } 2 \mathrm{~T} \rightarrow \mathrm{G}, \\
\text { d. IVS-2 nt } 849 \mathrm{~A} \rightarrow \mathrm{G}, \\
\text { e. IVS-2 nt } 849 \mathrm{~A} \rightarrow \mathrm{C} \\
\text { f. IVS-1 nt } 5 \mathrm{C} \rightarrow \mathrm{G}, \\
\text { g. IVS-1 nt } 5 \mathrm{G} \rightarrow \mathrm{T}, \\
\text { h. IVS-1 nt } 128 \mathrm{~T} \rightarrow \mathrm{G}, \\
\text { i. } \\
\text { IVS-2 nt } 843 \mathrm{~T} \rightarrow \mathrm{G}\end{array}$ & $\beta^{0}$ \\
\hline
\end{tabular}


DEFECT

TYPE OF THALASSEMIA

Mutations in the promoter region

4. Reduction in the mRNA transcription

a. $-101 \mathrm{C} \rightarrow \mathrm{T}$,

b. $-92 \mathrm{C} \rightarrow \mathrm{T}$,

c. $-88 \mathrm{C} \rightarrow \mathrm{T}$,

d. $-31 \mathrm{~A} \rightarrow \mathrm{G}$,

e. $-30 \mathrm{~T} \rightarrow \mathrm{A}$,

f. $\quad-28 \mathrm{~A} \rightarrow \mathrm{C}$

Mutations in polyadenylation site mRNA (AATAAA)
a. AACAAA,
b. AATAAG,
c. AATGAA,
d. AATAGA,
e. A (del AATAA)
a. CD 49+TG (Hb Agnana),
b. CD $110 \mathrm{TC}(\mathrm{Hb}$ Showa- Yakushiji),
c. $\mathrm{CD} 114-\mathrm{CT}+\mathrm{G}$ (Hb Genebra)

Structural Mutations (elongated chains or hyperunstable) $\quad \beta^{+}$

Table 1. Frequent examples of point mutations causing thalassemias in humam population, according to their location in the molecule, the functional defect associated and the consequence on globin synthesis.

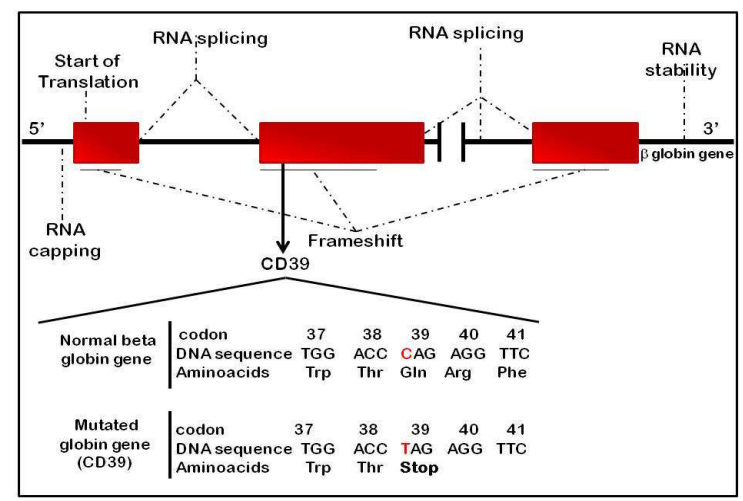

Fig. 7. Different types of point mutation involved in the development of $\beta$ Thal - Point mutations can alter the start of translation, RNA capping, the frameshift of protein translation and the RNA stability. The creation of a stop codon, as in the CD39 type of $\beta$ Thal, is responsible by a formation of a non-functional protein that is degraded causing $\beta^{0}$ thalassemia.

Specifically in the splicing process, which is necessary the recognition of specific sequences by the spliceosome in the intronic region, point mutations are responsible by the impaired globin production. In fact, various forms of $\beta$ Thal are caused by mutations that either 
damage the process of splicing of the mRNA precursor to mature mRNA in the nucleus or block translation of mRNA in the cytoplasm.

Some point mutations change the dinucleotide (GT) or (AG), which are extremely important in the exon-intron junctions on the conventional processing, completely block the production of mature RNA. Therefore, the $\beta$-globin molecules are not produced, leading to the appearance of a $\beta^{0}$ thalassemia.

Other mutations can change the consensus sequences surrounding the invariant dinucleotide AG and GT. This consequently decreases the efficiency of conventional splicing which shall occur at a level between $70 \%$ and $95 \%$, resulting in $\beta+$ talassemia. Another mechanism of change is the result of splicing mutations that do not occur close to any normal splice site. Such changes could occur in a region located in intron region which is crucial for regular splicing of the gene, called crypt splice sites. They resemble the consensus sequences of local splice, but usually do not support splicing. The mutations are able to activate these sites through the alteration to GT or AG site, generating a consensus sequence that stimulate the splicing machinery (Fig. 8) (Hoffman et al. 2008).

There may be mutations that suppres the translation in several regions along the mRNA, and it is a common cause of $\beta^{0}$ thalassemia. The most common form of $\beta^{0}$ thalassemia in people of the region of Sardinia (Italy) is the result of a base substitution, which changes the codon encoding the amino acid 39 of the $\beta$ globin gene (CAG-TAG), whose sequence equivalent (UAG) characterizes the termination of translation of the mRNA, forming a premature stop codon that prevents the ability of mRNA to be translated into normal $\beta$ globin. This phenomenon can also result in frameshift mutations causing small deletions or insertions of a few bases, or multiples of 3 , which alter the sequence of nucleotides that is read during translation (see Fig. 7).

Two groups of partial deletions of the $\beta$ gene are known: (i) loss of 600 bases before the start of the gene, including the exon 1, intron 1 and part of exon 2, and (ii) loss of 619 nucleotides at the end of $\beta$ gene. In both cases, the synthesis of $\beta$ chain does not occur. This type of $\beta$ Thal is common in northwestern India and on Pakistan (Khan et al. 1998; Madan et al. 1998).

A study in Turkey aiming to determine the origin of some of the mutations related to $\beta$ Thal identified twelve haplotypes, demonstrating a remarkable level of heterogeneity. From 22 analyzed mutations in the $\beta$-globin gene, 18 were related to a single sequence haplotype. This simple association encouraged an attempt to determine the origin of these mutations by comparing their frequencies in Turkey with other countries and / or the worldwide distribution of haplotype carrying them. However, the presence of several exceptions to "one haplotype / one mutation" cluster showed that the $\beta$-globin gene is not static. Each of the mutations - IVS-I-10 (G -> A), Cd 39 (C -> T), IVS-I-6 (T -> C) and -30 (T -> A) - in the $\beta$ globin was associated with a minimum of two sequences of haplotypes. This fact can be explained by the potential existence of recombination mechanisms which are continuously activated (Bilgen et al. 2011).

Some genetic factors may reduce phenotypic effects of some cases of $\beta$ Thal. A mechanism that exerts positive effects on $\beta$ Thal phenotypic traits is the decrease of the unbalanced production of the globin chains making the precipitation of these chains lower. 


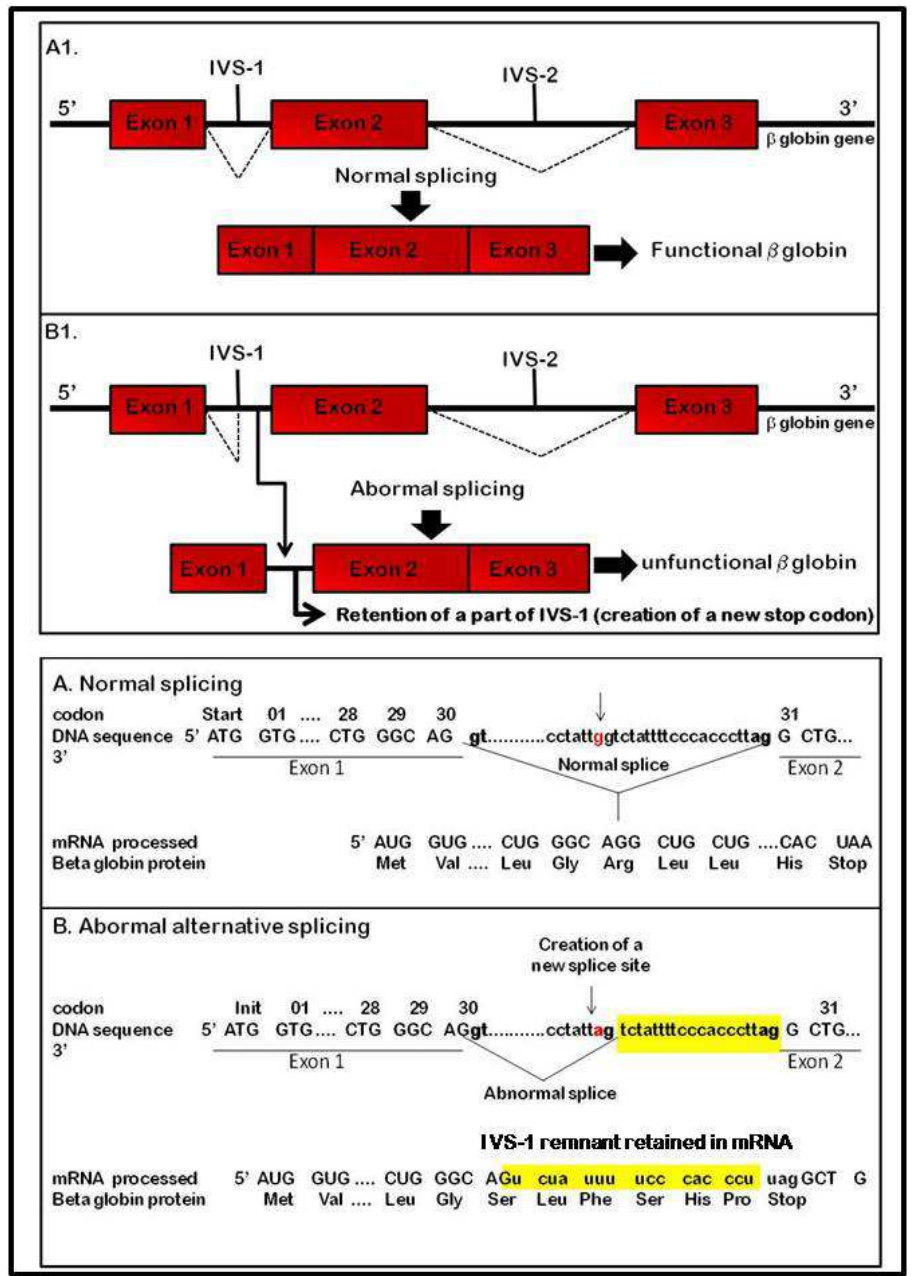

Fig. 8. Point mutations in the splicing sites are responsible for the formation of a nonfunctional hemoglobin - The introduction of point mutations in the splicing sites at intronic regions can create a new splicing site (highlighted in black) that can alter the structure of the $\beta$ globin through the retention of a portion of intron forming an non-functional globin polypeptide.

This feature leads to reduced production of $\alpha$ chains thus reducing the overall imbalance of $\alpha$ and $\beta$ chains. The persistence in the production of $\gamma$ globin also acts reducing the imbalance between the globin chains. This persistence of $\mathrm{HbF}$ production relies on the transmission co-genetic factors. Hereditary persistence of fetal hemoglobin (HPFH) in adults can be present in two forms according to the distribution of $\mathrm{HbF}$ within red blood cells, i. e. homogeneous or heterogeneous distribution. The aspects of this disorder will be discussed in the next section below. 


\section{Hereditary persistence of fetal hemoglobin}

The hereditary persistence of fetal hemoglobin $(\mathrm{HPFH})$ is a group of genetic disorders characterized by continued expression of fetal hemoglobin $(\mathrm{HbF})$ in adulthood. HPFH could be divided in (i) pancellular with homogeneus distribution of $\mathrm{HbF}$ among all red cells and (ii) heterocellular with an increase in $\mathrm{HbF}$ in some cells called F cells (Pace 2007).

On a molecular point of view, pancellular HPFH is in the most of cases caused by extensive deletions in the group $\beta$, called deletional HPFH (dHPFH). Point mutations in the promoter region of both $\gamma$ globin genes, called non-deletional HPFH (ndHPFH) are found in the most of cases diagnosed as heterocellular HPFH (Hoffman et al. 2008).

\subsection{Deletional HPFH}

The increase in $\mathrm{HbF}$ caused by $\mathrm{dHPFH}$ is associated with deletions in DNA sequences in the $\beta$ globin cluster, with the preservation of the $\gamma \mathrm{A}$ and $\gamma \mathrm{G}$ globin gene. Heterozygous individuals for delecional HPFH have an increase in the $\mathrm{HbF}$ up to $20 \%$ to $30 \%$ of total hemoglobin in the erythrocytes with homogeneous distribution (pancellular).

The mechanism responsible for the increase in $\mathrm{HbF}$ in $\mathrm{dHPFH}$ has not been completely elucidated. Some hypotheses have been proposed to explain these mechanisms and the more accepted one is that the deletion removes competitive regions of $\gamma$ globin gene like the $\delta$ and $\beta$ globin genes that under normal conditions would interact with the LCR, silencing the $\gamma$ globin expression and starting the $\mathrm{HbA}$ production. Together with the deletion of these genes, the removal of the silencer elements located in the region between genes $\gamma^{\mathrm{A}}$ and $\delta$ globin helps in the increment of $\mathrm{HbF}$ observed in this hematological disorder (Pace 2007; Ngo et al. 2011).

To date, six different types of dHPFHs have been characterized: The HPFH-1 and HPFH-2 is characterized as a large deletion of approximately $105 \mathrm{~kb}$ in DNA sequence of the $\delta$ and $\beta$ globin gene region; in the HPFH-3 and HPFH-4 the deletions are shorter with approximately $50 \mathrm{~kb}$ of DNA sequence from $\Psi \beta$ to $\beta$ globin removed; HPFH- 5 is the smaller deletion characterized by the removal of approximately $3 \mathrm{~kb}$ upstream to $\delta$ globin until 0.7 $\mathrm{kb}$ downstream from the $\beta$ globin gene. Finally HPFH-6 had similar deletions profiles observed in type 1 and 2 with the involvement of $\gamma^{A}$ globin gene deletion (Fig. 9)

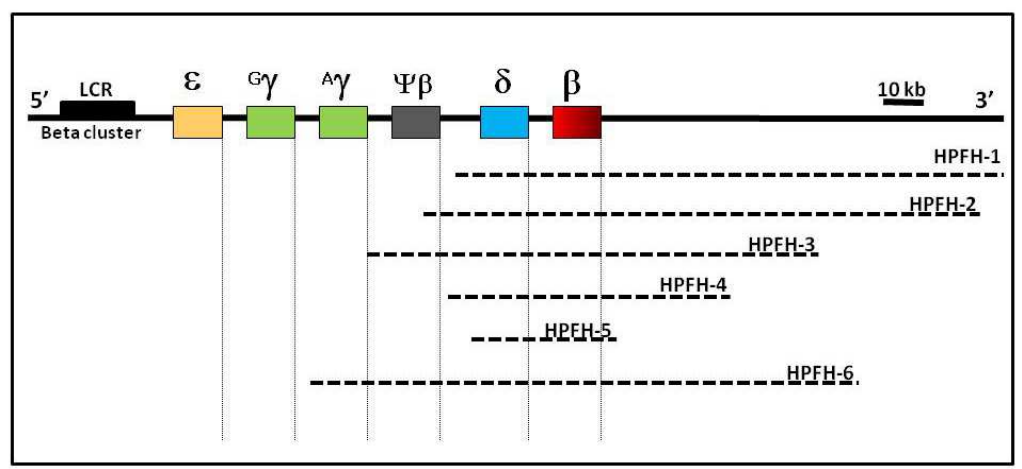

Fig. 9. The deletional form of HPFH - Position of deletions involved in the increase of fetal hemoglobin after the birth are shown in the $\beta$ globin gene cluster. 


\subsection{Non delecional HPFH}

The non deletional HPFH is characterized by a point mutation in the promoter region of the $\gamma^{\mathrm{G}}$ globin gene or the $\gamma^{\mathrm{A}}$ globin gene. In contrast to $\mathrm{dHPFH}$ there are several mutations involved in the increment of fetal globin in the ndHPFH that are clustered in three regions of the $\gamma$ gene promoters centered around positions $-200,-175$, and -115 of both $\gamma^{\mathrm{A}}$ and $\gamma^{\mathrm{G}}$, relative to the transcriptional start site Some examples of ndHPFHs described in the literature are: Georgiana type ( $\left.\gamma^{\mathrm{A}}-114 \mathrm{C}-\mathrm{T}\right)$, Greek type $\left(\gamma^{\mathrm{A}}-117 \mathrm{G}-\mathrm{A}\right)$; African type $\left(\gamma^{\mathrm{A}}-175\right.$ T-C), Brazilian type $\left(\gamma^{\mathrm{A}}-195 \mathrm{C}-\mathrm{G}\right)$, Italian type $\left(\gamma^{\mathrm{A}}-196 \mathrm{C}-\mathrm{T}\right)$, English type $\left(\gamma^{\mathrm{A}}-198 \mathrm{~T}-\mathrm{C}\right)$, African type $\left(\gamma^{\mathrm{A}}-202 \mathrm{C}-\mathrm{T}\right)$, Switzerland type $\left(\gamma^{\mathrm{G}}-110 \mathrm{~A}-\mathrm{C}\right)$, Algeria type $\left(\gamma^{\mathrm{G}}-114 \mathrm{C}-\mathrm{A}\right)$, Japanese type $\left(\gamma^{G}-114 C-T\right)$, Australian type $\left(\gamma^{G}-114 C-G\right)$ Sardinian type $\left(\gamma^{G}-175\right.$ T-C) and African type ( $\left.\gamma^{G}-202 C-G\right)$ (as summarized in (Pace 2007).

The mechanisms involved in the reactivation of $\gamma$ globin were not completely understood for the most mutations described. It is suggested that these mutations interfere with the specific binding of some elements, mainly transcription factors, restricting or facilitating the connection of elements, suppressing the binding of transcription activators.

Some studies support this hypothesis, since several authors identified many transcription factors that could interact with these regions which are able to activate the $\gamma$ globin promoter. In the ndHPFH English type, $-198 \mathrm{~T}-\mathrm{C}$, the creation of a new site of interaction, CACCC box occurs which has high affinity for the transcription factor SP1 therefore increasing the strength of the $\gamma^{\mathrm{A}}$ globin gene promoter (Ronchi et al. 1989; Fischer et al. 1990; Gumucio et al. 1991). This event allows the CACCC box interaction with the LCR, increasing the production of mRNA for $\gamma$ globin production. Besides SP1, Olave and colleagues identified in the same mutation (-198 T-C) another activator protein complex formed by DNMT1, CDC5-like protein, RAP74, SNEV and P52, that can bind to the promoter region of the $\gamma^{\mathrm{A}}$ globin gene, also reactivating the expression of this gene (Olave et al. 2007).

In the Greek type ndHPFH, the $-117 \mathrm{G}-\mathrm{A}$ mutation deletes the repressor binding site of the transcription factor NF-E3, reducing its interaction with the globin gene promoter $\gamma^{\mathrm{A}}$ allowing the interaction of CP-1, an activator of transcription (Mantovani et al. 1989).

Mutations -175 T-C and -173 T-C prevents the formation of the protein complex containing GATA-1, OCT-1 and other transcriptional factors. It is suggested that this protein complex contributes to the formation of a repressive chromatin structure in the region -170 to -191 of the globin $\gamma^{\mathrm{A}}$ promoter, leading to the silencing of this gene in erythrocytes. In addition, Magis and Martin hypothesized in 1995 that the transcription factor HMG1 binds in the region - 175 of the $\gamma^{\mathrm{A}}$ gene promoter and interacts with the GATA-1 (Magis et al. 1995).

The -195 mutation, that characterize the ndHPFH Brazilian type, was identified by Costa and colleagues in 1990, through the study of a Caucasian patient bearer of hereditary spherocytosis and splenectomized, with $\mathrm{HbF}$ levels of $7 \%\left(13.9 \%\right.$ of chains $\gamma^{\mathrm{G}}$ and $86.1 \%$ of chains $\gamma^{\mathrm{A}}$ ). Two brothers of these individuals also had elevated $\mathrm{HbF}(4.5 \%$ and $4.7 \%)$ with predominance of the $\gamma^{\mathrm{A}}$ chains, however, they were not suffering from spherocytosis (Costa et al. 1990). Analysis of DNA-protein interaction demonstrated that the increased synthesis of $\mathrm{HbF}$, due to the $-195 \mathrm{C}-\mathrm{G}$ mutation is not mediated by the protein and SP1 or a new site CACCC box creation (Takahashi et al. 2003). Thus, the mechanism of increased levels of $\mathrm{HbF}$ in patients with ndHPFH Brazilian type is different from the -198 mutation that occurs 
in the ndHPFH English type. In order to evaluate if the -195 mutation is able to increase the $\mathrm{HbF}$ in vivo, Cunha and colleagues in 2009 developed an in vivo study in which the -195 mutation was inserted into the $\gamma$ globin gene promoter at a $\beta$ globin cluster cloned in a cosmid. This construction was inserted in a transgenic mouse and through RT-PCR and RNAse Protection Assay (RPA) the authors demonstrated that the -195 mutation, together with all the $\beta$ globin cluster is enough to raise levels of $\mathrm{HbF}$ in all phases of development of transgenic mice. This observation was supported by an increase in $\gamma$ globin gene expression in yolk sac, fetal liver and other organs of these mice compared to expression in mice carrying the wild $\beta$ globin cluster. The results showed that the presence of the mutation -195 together with the entire $\beta$ globin cluster is sufficient to develop the phenotype of ndHPFH-B in mice (da Cunha et al. 2009). Even with these detailed studies, the complete mechanism involved in the reactivation of the globin gene in the Brazilian type $\gamma^{\mathrm{A}}$ ndHPFH is not elucidated.

Understanding the mechanisms involved in these mutations may be important for the development of new therapies based on reactivation of $\gamma$ globin gene which can assist in the treatment of hemoglobinopathies.

\section{Expression of gamma globin and the regulation of severity of sickle cell disease and beta thalassemia}

As we discussed above, in SCD a point mutation leads to a structural alteration in $\beta$ globin protein, that in absence of oxygen acquires the ability of forming long and multi-stranded fibers that alters the red blood cell shape increasing the destruction of these cells in spleen and liver and finally causing an important hemolytic anemia. In $\beta$ Thal, the point mutations or deletions observed in $\beta$ globin gene are responsible for altering the production of $\beta$ globin protein. In the most severe form of $\beta$ Thal, the $\beta$ thalassemia major, there is no production of this protein. As a result, the $\alpha$ globin normally produces precipitates inside the red blood cells leading to an increased destruction of these cells causing hemolytic anemia, as also observed in SCD patients. In both cases, when a high expression of $\gamma$ globin is observed, the patient has a very mild clinical disorder when compared to patients with a low expression of this protein. This better condition is due to the increment of production of fetal hemoglobin $(\mathrm{HbF})$, as we have presented before as caused by the assembly of two $\alpha$ chains with $2 \gamma$ chains $(\alpha 2 \gamma 2)$. The clinical benefit induced by the increase of $\mathrm{HbF}$ in SCD patients has been repeatedly demonstrated by several authors. In this disease, the beneficial effects of $\mathrm{HbF}$ is due to its interaction with the $\mathrm{HbS}$ polypeptide, that form an asymmetric hybrid hemoglobin, referred to as $\mathrm{HbF} / \mathrm{S}\left(\alpha 2 \gamma \beta^{\mathrm{S}}\right)$. This molecul directly affects the stability of the sickle hemoglobin polymer, preventing its deleterious alteration in cell morphology. Moreover, the premature destruction of sickle erythrocytes increases the number of cells where $\mathrm{HbF}$ concentration is high (Pace 2007).

Several studies over the last 20 years attempted to identify pharmacological agents able to increase the $\mathrm{HbF}$ in these patients. Several compounds that broadly influence epigenetic modifications, including DNA methylation and histone deacetylation were tested.

In the beginning of 1990, the use of Hydroxyurea (HU) was proposed for the treatment of SCD patients. This compound was firstly synthesized in 1869 and is widely used as an antineoplastic drug mainly employed to traet myeloproliferative disorders. During the 90 's 
several experiments were conducted mainly by the Multicenter Study of Hydroxyurea in Sickle Cell Anemia (MSH) and the results showed that HU were able to decrease the morbidity of SCA in adults, reducing the incidence of painful episodes and acute chest syndrome. These studies also revealed that this compound could be used to increase fetal hemoglobin $(\mathrm{HbF})$ concentration therefore reducing the vaso-occlusive complications and diminishing hemolysis (Steinberg et al. 2003). The ability of HU in the generation of Nitric Oxide (NO) is reported as the main property which can partially explain the augment of $\gamma$ globin production. In this sense, NO could act as a second messenger in a signaling cascade leading to the activation of several important genes. The results found in these first studies triggered other trials that used $\mathrm{HU}$ in $\beta$ Thal. Although the results were considered very promising, the augment of $\mathrm{HbF}$ in $\beta$ Thal was not observed in all patients (Lou et al. 2009).

To date, HU is the most widely used drug for adult SCD patients and is also highly used in $\beta$ thalassemia patients. Despite of several studies addressing this issue, the metabolic pathways and the set of genes expressed upon induction by HU are not completely known. Recently, some studies have evaluated patients and cultured cells before and after HU treatment in order to identify metabolic pathways and genes that could shed some light in the mechanism of action of this drug. In one of these studies conducted in 2006 by Costa et al, the mechanisms surrounding the in vivo action of HU were evaluated using a global gene expression analysis in cells obtained from the bone marrow of a SCD patient before and after HU treatment. The results suggested that $\mathrm{HU}$ induced significant changes in the gene expression pattern of SCD patient, mainly in global signal transduction pathways. This gene expression alteration may have a direct effect in the induction of globin genes and in genes associated with channel or pore class transporter. These pore transporter genes are thought to interfere in the hydratation status of cells, interfering with the rheological properties of them, what is very important in SCD (Costa et al. 2007). Having the same objectives and similar experimental design, another important study was conducted by Moreira et al (2007) using suppression subtractive hybridization (SSH) in HU-treated and -untreated reticulocytes of patients with SCD . In this report, similar pathways initially described by Costa were also identified after HU treatment. Additionally were also found some genes involved in chromatin modifications like SUDS3, FZD5 and PHC3. Although these studies have contributed to elucidate the transcriptional response influenced by $\mathrm{HU}$, the molecular mechanisms involved in $\mathrm{HU}$ treatment remain unclear (Moreira et al. 2008).

After the demonstration that some chemical agents are able to increase $\mathrm{HbF}$ concentration many efforts have been developed in order to find other inducers or a combination of agents able in ameliorate the symptoms of SCD and $\beta$ Thal. Several potential therapeutic agents and its combination have been investigated to use in these hemoglobinopathies. Table 2 shows some clinical trials used in $\beta$ Thal patients and their hematologic responses.

Despite the clear beneficial effects observed after HU treatment, the use of this pharmacological agent is limited since long-term treatment has been associated with several deleterious effects. In order to diminish the HU treatment effects many efforts are made to find new therapeutic alternatives to treat SCD symptoms without side effects. Recently, dos Santos et al designed a new molecule by molecular hybridization combining portions of thalidomide and HU and tested as potential use in the oral treatment of sickle cell disease symptoms. The results showed that this molecule was able to increase the levels of NO 
donor, as observed in HU treatment, and also demonstrated that different from what is observed in HU treatment, this new molecule had analgesic and anti-inflamatory properties, reducing the levels of tumor necrosis factor $\alpha(\mathrm{TNF} \alpha)$ thus representing an alternative approach to HU treatment (dos Santos et al. 2011).

\begin{tabular}{|c|c|c|c|c|}
\hline Terapeutic Agent & Action & $\begin{array}{l}\text { Thalassemia } \\
\text { Syndromes }\end{array}$ & $\begin{array}{l}\text { Increase in Total } \\
\mathrm{Hb}(\mathrm{g} / \mathrm{dl}) \text { (range) }\end{array}$ & Responses \\
\hline 5- Azacytidine & $\begin{array}{l}\text { Hypomethylation } \\
+/ \text { - cytotoxicity }\end{array}$ & $\begin{array}{l}\text { Thalassemia } \\
\text { Intermedia }\end{array}$ & $2.5[1.5-4]$ & $\begin{array}{l}1 / 1 \\
1 / 1 \\
3 / 3\end{array}$ \\
\hline $\begin{array}{l}\text { Hydroxyurea } \\
(\mathrm{HU})\end{array}$ & $\begin{array}{l}\text { Cytotoxicity and } \\
\text { erythroid regeration } \\
\rightarrow \text { high- F BFU- E }\end{array}$ & $\begin{array}{l}\mathrm{HbE} / \beta- \\
\text { talassemia } \\
\text { Thalassemia } \\
\text { Intermedia } \\
\mathrm{HbE} / \beta- \\
\text { talassemia }\end{array}$ & $\begin{array}{l}20[1-3.3] \\
27[2.2-3.2] \\
0.6[0-1.7] \\
1.0 \\
0.9\end{array}$ & $\begin{array}{l}3 / 3 \\
2 / 2(\beta \text { globin }) \\
11 / 13 \\
3 / 8 \\
7 / 19\end{array}$ \\
\hline $\begin{array}{l}\text { Sodium } \\
\text { Phenybutyrate } \\
\text { (SPB) }\end{array}$ & ? HDACi effect & $\begin{array}{l}\text { Thalassemia } \\
\text { Intermedia and } \\
\text { Major }\end{array}$ & $2.1[1.2-2.8]$ & 4/8 untransfused \\
\hline $\begin{array}{l}\text { Arginine Butyrate } \\
\text { and } \mathrm{AB}+ \\
\text { Erithropoietin } \\
\text { (EPO) }\end{array}$ & $\begin{array}{l}\text { Activates y globin } \\
\text { gene promoter, (SSP } \\
\text { binding), (? } \\
\text { HDACi effect) }\end{array}$ & $\begin{array}{l}\text { Thalassemia } \\
\text { Intermedia and } \\
\text { Major }\end{array}$ & $2.7[0.6-5]$ & $7 / 10(\mathrm{AB}+/-\mathrm{EPO})$ \\
\hline Isobutyramide & $\begin{array}{l}\text { Activates } \gamma \text { globin } \\
\text { gene promoter }\end{array}$ & $\begin{array}{l}\text { Thalassemia } \\
\text { Intermedia and } \\
\text { Major }\end{array}$ & $\begin{array}{l}\text { Increase in } \mathrm{HbF} \text {, } \\
\text { Reduced } \\
\text { Transfusion } \\
\text { Requeriments }\end{array}$ & $\begin{array}{l}6 / 10 \\
2 / 4\end{array}$ \\
\hline EPO & $\begin{array}{l}\text { Stimulates Erythroid } \\
\text { Proliferation, } \\
\text { promotes erythroid } \\
\text { cell survival }\end{array}$ & $\begin{array}{l}\text { Thalassemia } \\
\text { Intermedia and } \\
\text { Major }\end{array}$ & $\begin{array}{l}2[1-3] \\
2.5 \\
2 \\
\text { Reduced } \\
\text { Transfusion } \\
\text { Requeriments }\end{array}$ & $\begin{array}{l}5-7 / 10 \\
4 / 4 \\
8 / 10 \\
3 / 26 \\
5 / 10\end{array}$ \\
\hline Darbepoietin & $\begin{array}{l}\text { Stimulates } \\
\text { Erythropoiesis }\end{array}$ & $\begin{array}{l}\text { Thalassemia } \\
\text { Intermedia }\end{array}$ & $1.6[0.7-3.8]$ & $4 / 6$ \\
\hline $\mathrm{HU}+\mathrm{EPO}$ & As Above & $\begin{array}{l}\text { Thalassemia } \\
\text { Intermedia } \\
\mathrm{HbE} / \beta- \\
\text { talassemia }\end{array}$ & $\begin{array}{l}1.7[0.5-4] \\
1.2\end{array}$ & $1 / 5$ \\
\hline $\mathrm{HU}+\mathrm{SPB}$ & As Above & $\beta$ Lepore & $3[2-4]$ & $2 / 2$ \\
\hline
\end{tabular}

Table 2. Hematologic Responses to Fetal Globin Gene Inducers or Erithropoietin (EPO) in $\beta$ Thal Patients (Perrine 2005). 


\section{Molecular biology and the identification of targets to treat SCD and beta thalassemia diseases}

It has been a very well established concept the benefits in the increment of $\gamma$-globin levels in the treatment of patients SCD or $\beta$ Thal (Cao et al. 2011; Ngo et al. 2011).

Therefore the development of new therapies targeting the increment of $\gamma$ globin production can become possible through the identification of the molecular mechanisms involved in fetal globin gene silencing and its reactivation which needs to be known in depth. An excellent model to study these mechanisms is the HPFH, a disorder in which the $\gamma$ globin production is not silenced, as described above. The mechanisms involved in the reactivation of $\gamma$ globin have been scrutinized in several studies. Olave et al. studied the proteins able to bind at the $\gamma$ globin promoter in the presence of a point mutation that leads to an English form of HPFH $(-198 \mathrm{~T} \rightarrow \mathrm{C})$. The results showed that a protein complex binds to this region and is able to increase the HbF production. The authors suggested that DNMT1 protein, one member of this putative complex, acts as a chromatin remodeling protein opening the chromatin and triggering the $\gamma$ globin expression (Olave et al. 2007). In another interesting study developed by Andrade et al., the pattern of gene expression was evaluated in reticulocytes of an individual with the deletional form of PHHF. In this study the authors also identified the up-regulation of chromatin remodeling proteins (ARID1B and TSPYL1) as also involved in the reactivation of $\gamma$ globin (de Andrade et al. 2006).

Despite the studies with HPFH, several authors have described the interaction of genes with the activation or silencing of $\gamma$ globin promoter. Among these genes EKLF has been pointed out in numerous reports as the main responsible for the regulation of $\beta$ globin expression. The increase in the expression of this gene occurs in accordance with the increase of $\beta$ globin producing and $\gamma$ globin silencing. The main function of this protein seems to be in the activation of another gene called BCL11A whose gene product is able to bind at $\gamma$ globin genes promoter repressing its transcription (Figure 10). The control of EKLF and BCL11A production could be further explored as a therapeutical strategy to increase the production of $\mathrm{HbF}$ and ameliorate hemoglobin disorders such as $\beta$ Thal and sickle cell disease (Sankaran et al. 2008; Xu et al. 2010; Jawaid et al. 2011; Wilber et al. 2011).

Another important contribution aiming to clarify the understanding of $\gamma$-globin genes silencing is the results found in the analysis of the hematopoietic transcription factor GATA1. This gene, as we discussed before is a zinc finger protein that binds to WGATAR elements located mainly in the regulatory regions of erythroid genes, including the $\alpha$ and $\beta$ globin genes (Weiss et al. 1995; Weiss et al. 1997).

A direct interaction between GATA1 and $\gamma$-globin silencing was highlighted in two different studies. In the first one, the authors showed the importance of a 352-bp region harboring a conserved GATA element at position -566 5' of the HBG1 is required for $\gamma$-globin silencing in transgenic mice. In the second report, the authors correlated a mutation found in GATA site in the HBG2 gene with the increase in $\gamma$ globin expression in a family with HPFH. These results showed that GATA- 1 can act as a repressor of $\gamma$ globin gene despite its widely described role in the literature as an activator of $\alpha$ and $\beta$ globin genes. The mechanism whereby GATA-1 exerts these distinct functions remains unresolved. Some evidences 


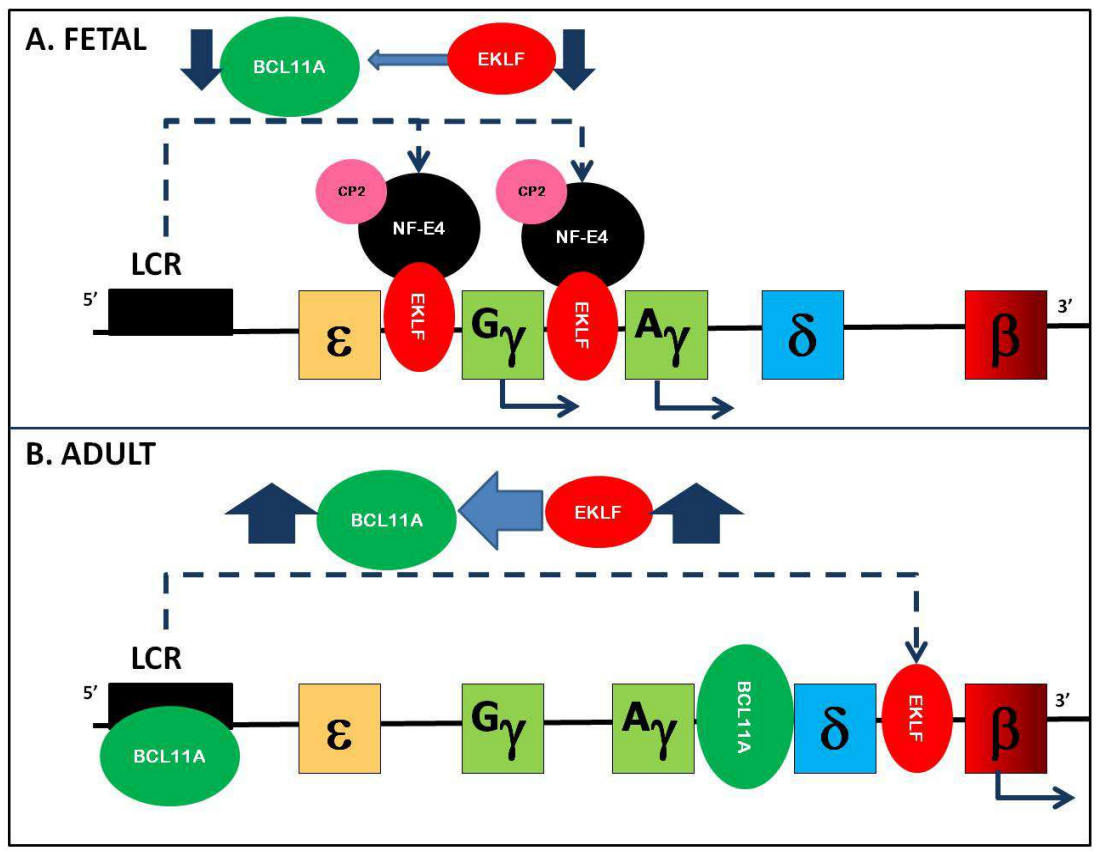

Fig. 10. EKLF levels coordinate the hemoglobin switching. The activation of globin genes is dependent of the production of EKLF protein. A low level of EKLF is observed during the fetal stage. Since EKLF is essential for the activation of BCL11A, low levels of this gene is also reduced. The lowly expressed BCL11A is unable to repress $\gamma$-globin genes and EKLF with the recruitment of the NFE4 and CP2, preferentially interacts with the $\gamma$-globin promoters. This interaction stimulates the assembly of LCR elements activating the production of $\gamma$-globin protein and consequently the $\mathrm{HbF}$ formation. In the adult stage, high levels of EKLF is observed. The increase of this protein promotes an overexpression of BCL11A ultimately repressing the $\gamma$-globin genes under these circunstances. In this situation the EKLF binds preferentially to the $\beta$-globin promoter activating the $\beta$-globin gene with the recruitment of the LCR. This figure was adapted from (Wilber et al. 2011).

showed that this repression mechanisms could occurs via two other genes: FOG-1 and $N u R D$. FOG-1 is also a zinc finger protein that binds to GATA-1 acting as an important player in both activation and repression of genes modulated by GATA-1. FOG-1 interacts with several protein complexes, including NuRD (nucleosome remodeling and histone deacetylase), that is a co-repressor complex that interacts with several N-terminal motifs found in other transcriptional repressors, for instance, the BCL11A gene. In an experiment using transgenic mice bearing three different mutations that completely abrogate the binding between NuRD and FOG-1, the authors showed that animals homozygous for these mutations were anemic and displayed defects in platelet formation. These results indicate that this interaction is essential for normal erythroid and megakaryocyte development. The same authors concluded that the FOG-1/NuRD interaction is indispensable for the 
expression of $\beta$-globin gene and this interaction was not required for the repression of human $\gamma$-globin in vivo (Miccio et al. 2010; Xu et al. 2010).

Despite several attempts, the complete molecular mechanism involved in the switching of globins and the reactivation of $\gamma$ globin remains to be elucidated. Is clear that chromatin remodeling in the $\gamma$ globin region is the main process whereby $\mathrm{HbF}$ reactivation occurs, once the expression of genes involved in this process are found in most of gene expression profiling studies using HPFH as a model. However, additional studies are necessary in order to identify a complete overview of metabolic pathways able to increase the $\mathrm{HbF}$ production and raise the possibility for the identification of new targets that could be used as therapeutical agents to treat SCD and $\beta$ Thal.

\section{Conclusion}

The mechanisms underlying the hemolytic anemia are very complex and the prognosis of this group of diseases is greatly influenced by the gain or loss-of function in key genes involved in the regulation of synthesis and destruction of globin proteins. Several molecular events can be linked to the alteration in gene function. In this chapter, we focused on point mutations interfering in the nature and the severity of SCD and $\beta$ Thal. The comprehension of the molecular basis and the identification of proteins involved in the onset and development of a disease can enable the development of drugs specially designed to targeted therapy. There are some well succeeded examples of the use of molecular biology to design drugs to treat a specific disease. One of the most classical examples comes from the study of another hematological disease: the Chronic Myeloid Leukemia (CML). The development of this CML is characterized by the expression of a BCR-ABL protein produced by a genetic translocation event. Using molecular biology approaches, the BCRABL inhibitor imatinib was the first molecular targeted cancer therapy designed to bind inactive the translocated product of BCR-ABL protein. The employment of such molecular approach in the field of hemolytic anemias can open up new avenues of investigation taking advantage of the large scale studies to found new point mutation in genes involved in these diseases and correlate with the prognosis of each patient. Although many decades of efforts have been devoted to the mechanism elucidation of these diseases, much more remains to be done concerning to the identification of new point mutations conferring function on the disease progression,. In this context, the current scenery worldwide seen to be very prolific due to the recent large investments in the genomic revolution of next generation sequencing approaches. These approachs can be easely exploited through the large scale transcriptome (RNAseq) dissecation of hemolytic anemias. It may provide interesting links between the expressed genes by a specific disease, such as SCD and ßthal, and help in better understanding the association between the mutations and the metabolic pathways activated in each case. Thus the dissection of the involved metabolic pathways can identify key genes responsible for the disease development and progression. In addition, although important studies using molecular biology techniques highlighted the function of several genes involved in the hemolytic anemias, several questions are currently partially understood. For example, what are the transcriptome and proteome difference between patients that have the same mutations causing $\beta$ Thal but that have different phenotypes (major and intermedia)? The answer for this question is a promising strategy to identify new genes 
involved in the severity of these disease. Also, which are the genes that are modulated in each type of HPFH? The identification of these genes could help in the elaboration of new therapies to increase the fetal hemoglobin in SCD and $\beta$ Thal. Once the modulation and severity of these diseases is strictly correlated with mutations and haplotypes, this feature make them a very interesting and fruitful model for study of point mutation and genome plasticity using molecular biology approach seeking for further improvements for patients built on the field regenerative medicine and genetic therapy.

\section{Acknowledgment}

The authors would like to thank fundings from the Brazilian agencies FAPESP (Fundação de Amparo à Pesquisa do Estado de São Paulo) and CAPES (Coordenação de Aperfeiçoamento de Pessoal de Nível Superior)

\section{References}

Bilgen, T., Y. Arikan, D. Canatan, A. Yesilipek and I. Keser (2011). "The association between intragenic SNP haplotypes and mutations of the beta globin gene in a Turkish population." Blood Cells Mol Dis 46(3): 226-9.

Blobel, G. A., T. Nakajima, R. Eckner, M. Montminy and S. H. Orkin (1998). "CREB-binding protein cooperates with transcription factor GATA-1 and is required for erythroid differentiation." Proc Natl Acad Sci U S A 95(5): 2061-6.

Blobel, G. A. and S. H. Orkin (1996). "Estrogen-induced apoptosis by inhibition of the erythroid transcription factor GATA-1." Mol Cell Biol 16(4): 1687-94.

Blobel, G. A., C. A. Sieff and S. H. Orkin (1995). "Ligand-dependent repression of the erythroid transcription factor GATA-1 by the estrogen receptor." Mol Cell Biol 15(6): 3147-53.

Cao, A. and R. Galanello (2010). "Beta-thalassemia." Genet Med 12(2): 61-76.

Cao, A., P. Moi and R. Galanello (2011). "Recent advances in beta-thalassemias." Pediatr Rep 3(2): e17.

Carlson, J., G. B. Nash, V. Gabutti, F. al-Yaman and M. Wahlgren (1994). "Natural protection against severe Plasmodium falciparum malaria due to impaired rosette formation." Blood 84(11): 3909-14.

Costa, F. C., A. F. da Cunha, A. Fattori, T. de Sousa Peres, G. G. Costa, T. F. Machado, D. M. de Albuquerque, S. Gambero, C. Lanaro, S. T. Saad and F. F. Costa (2007). "Gene expression profiles of erythroid precursors characterise several mechanisms of the action of hydroxycarbamide in sickle cell anaemia." $\mathrm{Br} J$ Haematol 136(2): 333-42.

Costa, F. F., M. A. Zago, G. Cheng, J. F. Nechtman, T. A. Stoming and T. H. Huisman (1990). "The Brazilian type of nondeletional A gamma-fetal hemoglobin has a C---G substitution at nucleotide -195 of the A gamma-globin gene." Blood 76(9): 18967.

da Cunha, A. F., A. F. Brugnerotto, M. A. Corat, E. E. Devlin, A. P. Gimenes, M. B. de Melo, L. A. Passos, D. Bodine, S. T. Saad and F. F. Costa (2009). "High levels of human gamma-globin are expressed in adult mice carrying a transgene of the Brazilian 
type of hereditary persistence of fetal hemoglobin ((A)gamma -195)." Hemoglobin 33(6): 439-47.

de Andrade, T. G., K. R. Peterson, A. F. Cunha, L. S. Moreira, A. Fattori, S. T. Saad and F. F. Costa (2006). "Identification of novel candidate genes for globin regulation in erythroid cells containing large deletions of the human beta-globin gene cluster." Blood Cells Mol Dis 37(2): 82-90.

dos Santos, J. L., C. Lanaro and C. M. Chin (2011). "Advances in sickle cell disease treatment: from drug discovery until the patient monitoring." Cardiovasc Hematol Agents Med Chem 9(2): 113-27.

Ducamp, S., C. Kannengiesser, M. Touati, L. Garcon, A. Guerci-Bresler, J. F. Guichard, C. Vermylen, J. Dochir, H. A. Poirel, F. Fouyssac, L. Mansuy, G. Leroux, G. Tertian, R. Girot, H. Heimpel, T. Matthes, N. Talbi, J. C. Deybach, C. Beaumont, H. Puy and B. Grandchamp (2010). "Sideroblastic anemia: molecular analysis of the ALAS2 gene in a series of 29 probands and functional studies of 10 missense mutations." Hum Mutat 32(6): 590-7.

Fischer, K. D. and J. Nowock (1990). "The T----C substitution at -198 of the A gamma-globin gene associated with the British form of HPFH generates overlapping recognition sites for two DNA-binding proteins." Nucleic Acids Res 18(19): 5685-93.

Ghaffari, S. (2008). "Oxidative stress in the regulation of normal and neoplastic hematopoiesis." Antioxid Redox Signal 10(11): 1923-40.

Greer, J. P., J. Foerrster, G. Rodgers, F. Paraskevas, B. Glader, D. A. Arber and J. Means, R. T. (2008). Wintrobe's clinical hematology, Lippincott Williams \& Wilkins

Gumucio, D. L., K. L. Rood, K. L. Blanchard-McQuate, T. A. Gray, A. Saulino and F. S. Collins (1991). "Interaction of Sp1 with the human gamma globin promoter: binding and transactivation of normal and mutant promoters." Blood 78(7): 185363.

Hoffman, R., B. Furie, P. McGlave, P. E. Silberstein, S. J. Shattil, E. J. Benz Jr. and H. Heslop (2008). Hematology: Basic Principles and Practice. New York, Churchil Livingstone ELSEVIER.

Ingram, V. M. (1957). "Gene mutations in human haemoglobin: the chemical difference between normal and sickle cell haemoglobin." Nature 180(4581): 326-8.

Jawaid, K., K. Wahlberg, S. L. Thein and S. Best (2011). "Binding patterns of BCL11A in the globin and GATA1 loci and characterization of the BCL11A fetal hemoglobin locus." Blood Cells Mol Dis 45(2): 140-6.

Khan, S. N. and S. Riazuddin (1998). "Molecular characterization of beta-thalassemia in Pakistan." Hemoglobin 22(4): 333-45.

Lou, T. F., M. Singh, A. Mackie, W. Li and B. S. Pace (2009). "Hydroxyurea generates nitric oxide in human erythroid cells: mechanisms for gamma-globin gene activation." Exp Biol Med (Maywood) 234(11): 1374-82.

Madan, N., S. Sharma, U. Rusia, S. Sen and S. K. Sood (1998). "Beta-thalassaemia mutations in northern India (Delhi)." Indian J Med Res 107: 134-41.

Magis, W. and D. I. Martin (1995). "HMG-I binds to GATA motifs: implications for an HPFH syndrome." Biochem Biophys Res Commun 214(3): 927-33. 
Mantovani, R., G. Superti-Furga, J. Gilman and S. Ottolenghi (1989). "The deletion of the distal CCAAT box region of the A gamma-globin gene in black HPFH abolishes the binding of the erythroid specific protein NFE3 and of the CCAAT displacement protein." Nucleic Acids Res 17(16): 6681-91.

Miccio, A. and G. A. Blobel (2010). "Role of the GATA-1/FOG-1/NuRD pathway in the expression of human beta-like globin genes." Mol Cell Biol 30(14): 3460-70.

Moreira, L. S., T. G. de Andrade, D. M. Albuquerque, A. F. Cunha, A. Fattori, S. T. Saad and F. F. Costa (2008). "Identification of differentially expressed genes induced by hydroxyurea in reticulocytes from sickle cell anaemia patients." Clin Exp Pharmacol Physiol 35(5-6): 651-5.

Nagel, R. L., M. E. Fabry, J. Pagnier, I. Zohoun, H. Wajcman, V. Baudin and D. Labie (1985). "Hematologically and genetically distinct forms of sickle cell anemia in Africa. The Senegal type and the Benin type." N Engl J Med 312(14): 880-4.

Ngo, D. A., B. Aygun, I. Akinsheye, J. S. Hankins, I. Bhan, H. Y. Luo, M. H. Steinberg and D. H. Chui (2011). "Fetal haemoglobin levels and haematological characteristics of compound heterozygotes for haemoglobin $S$ and deletional hereditary persistence of fetal haemoglobin." Br J Haematol.

Olave, I. A., C. Doneanu, X. Fang, G. Stamatoyannopoulos and Q. Li (2007). "Purification and identification of proteins that bind to the hereditary persistence of fetal hemoglobin -198 mutation in the gamma-globin gene promoter." J Biol Chem 282(2): 853-62.

Pace, B. (2007). Renaissance of Sickle Cell Disease research in the genome era. London, Imperial College Press.

Pagnier, J., J. G. Mears, O. Dunda-Belkhodja, K. E. Schaefer-Rego, C. Beldjord, R. L. Nagel and D. Labie (1984). "Evidence for the multicentric origin of the sickle cell hemoglobin gene in Africa." Proc Natl Acad Sci U S A 81(6): 1771-3.

Palstra, R. J., B. Tolhuis, E. Splinter, R. Nijmeijer, F. Grosveld and W. de Laat (2003). "The beta-globin nuclear compartment in development and erythroid differentiation." Nat Genet 35(2): 190-4.

Pauling, L., H. A. Itano and et al. (1949). "Sickle cell anemia a molecular disease." Science 110(2865): 543-8.

Perrine, S. P. (2005). "Fetal globin induction--can it cure beta thalassemia?" Hematology Am Soc Hematol Educ Program: 38-44.

Powars, D. R., H. J. Meiselman, T. C. Fisher, A. Hiti and C. Johnson (1994). "Beta-S gene cluster haplotypes modulate hematologic and hemorheologic expression in sickle cell anemia. Use in predicting clinical severity." Am J Pediatr Hematol Oncol 16(1): 55-61.

Ronchi, A., S. Nicolis, C. Santoro and S. Ottolenghi (1989). "Increased Sp1 binding mediates erythroid-specific overexpression of a mutated (HPFH) gamma-globulin promoter." Nucleic Acids Res 17(24): 10231-41.

Sankaran, V. G., T. F. Menne, J. Xu, T. E. Akie, G. Lettre, B. Van Handel, H. K. Mikkola, J. N. Hirschhorn, A. B. Cantor and S. H. Orkin (2008). "Human fetal hemoglobin expression is regulated by the developmental stage-specific repressor BCL11A." Science 322(5909): 1839-42. 
Shapiro, B. S., D. F. Dinges, E. C. Orne, N. Bauer, L. B. Reilly, W. G. Whitehouse, K. OheneFrempong and M. T. Orne (1995). "Home management of sickle cell-related pain in children and adolescents: natural history and impact on school attendance." Pain 61(1): 139-44.

Stamatoyannopoulos, G. (2005). "Control of globin gene expression during development and erythroid differentiation." Exp Hematol 33(3): 259-71.

Steinberg, M. H., F. Barton, O. Castro, C. H. Pegelow, S. K. Ballas, A. Kutlar, E. Orringer, R. Bellevue, N. Olivieri, J. Eckman, M. Varma, G. Ramirez, B. Adler, W. Smith, T. Carlos, K. Ataga, L. DeCastro, C. Bigelow, Y. Saunthararajah, M. Telfer, E. Vichinsky, S. Claster, S. Shurin, K. Bridges, M. Waclawiw, D. Bonds and M. Terrin (2003). "Effect of hydroxyurea on mortality and morbidity in adult sickle cell anemia: risks and benefits up to 9 years of treatment." Jama 289(13): 1645-51.

Strauss, E. C., N. C. Andrews, D. R. Higgs and S. H. Orkin (1992). "In vivo footprinting of the human alpha-globin locus upstream regulatory element by guanine and adenine ligation-mediated polymerase chain reaction." Mol Cell Biol 12(5): 213542.

Strauss, E. C. and S. H. Orkin (1992). "In vivo protein-DNA interactions at hypersensitive site 3 of the human beta-globin locus control region." Proc Natl Acad Sci U S A 89(13): 5809-13.

Takahashi, T., R. Schreiber, J. E. Krieger, S. T. Saad and F. F. Costa (2003). "Analysis of the mechanism of action of the Brazilian type (Agamma-195 C --> G) of hereditary persistence of fetal hemoglobin." Eur J Haematol 71(6): 418-24.

Tang, Y., Y. Huang, W. Shen, G. Liu, Z. Wang, X. B. Tang, D. X. Feng, D. P. Liu and C. C. Liang (2008). "Cluster specific regulation pattern of upstream regulatory elements in human alpha- and beta-globin gene clusters." Exp Cell Res 314(1): 115-22.

Telen, M. and R. Kaufman (1999). The mature erythrocyte. Wintrobe's Clinical Hematology. J. Greer and F. J. Philadelphia, Lippincott Williams \& Wilkins: 217-47.

Thein, S. L. (1998). "Beta-thalassaemia." Baillieres Clin Haematol 11(1): 91-126.

Tsiftsoglou, A. S., I. S. Vizirianakis and J. Strouboulis (2009). "Erythropoiesis: model systems, molecular regulators, and developmental programs." IUBMB Life 61(8): 800-30.

Weiss, M. J., G. Keller and S. H. Orkin (1994). "Novel insights into erythroid development revealed through in vitro differentiation of GATA-1 embryonic stem cells." Genes Dev 8(10): 1184-97.

Weiss, M. J. and S. H. Orkin (1995). "Transcription factor GATA-1 permits survival and maturation of erythroid precursors by preventing apoptosis." Proc Natl Acad Sci U S A 92(21): 9623-7.

Weiss, M. J., C. Yu and S. H. Orkin (1997). "Erythroid-cell-specific properties of transcription factor GATA-1 revealed by phenotypic rescue of a gene-targeted cell line." Mol Cell Biol 17(3): 1642-51.

Wheatherall, D. J. and J. B. Clegg (2001). The Thalassemia Syndromes, Blackwell Science Ltd.

Wilber, A., A. W. Nienhuis and D. A. Persons (2011). "Transcriptional regulation of fetal to adult hemoglobin switching: new therapeutic opportunities." Blood 117(15): 394553. 
Xu, J., V. G. Sankaran, M. Ni, T. F. Menne, R. V. Puram, W. Kim and S. H. Orkin (2010). "Transcriptional silencing of \{gamma\}-globin by BCL11A involves long-range interactions and cooperation with SOX6." Genes Dev 24(8): 783-98. 


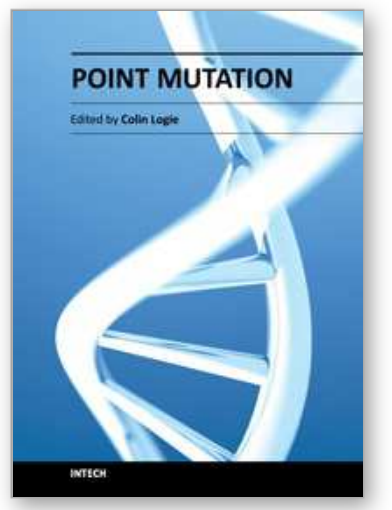

\author{
Point Mutation \\ Edited by Dr Colin Logie
}

ISBN 978-953-51-0331-8

Hard cover, 352 pages

Publisher InTech

Published online 21, March, 2012

Published in print edition March, 2012

This book concerns the signatures left behind in chromosomes by the forces that drive DNA code evolution in the form of DNA nucleotide substitutions. Since the genetic code predetermines the molecular basis of life, it could have been about any aspect of biology. As it happens, it is largely about recent adaptation of pathogens and their human host. Nine chapters are medically oriented, two are bioinformatics-oriented and one is technological, describing the state of the art in synthetic point mutagenesis. What stands out in this book is the increasing rate at which DNA data has been amassed in the course of the past decade and how knowledge in this vibrant research field is currently being translated in the medical world.

\title{
How to reference
}

In order to correctly reference this scholarly work, feel free to copy and paste the following:

Anderson Ferreira da Cunha, Iran Malavazi, Karen Simone Romanello and Cintia do Couto Mascarenhas (2012). Correlations with Point Mutations and Severity of Hemolitic Anemias: The Example of Hereditary Persistence of Fetal Hemoglobin with Sickle Cell Anemia and Beta Thalassemia, Point Mutation, Dr Colin Logie (Ed.), ISBN: 978-953-51-0331-8, InTech, Available from: http://www.intechopen.com/books/pointmutation/point-mutation-and-hemolytic-anemia-the-role-of-hereditary-persistence-of-fetal-hemoglobin-in-these

\section{INTECH}

open science | open minds

\author{
InTech Europe \\ University Campus STeP Ri \\ Slavka Krautzeka 83/A \\ 51000 Rijeka, Croatia \\ Phone: +385 (51) 770447 \\ Fax: +385 (51) 686166 \\ www.intechopen.com
}

\author{
InTech China \\ Unit 405, Office Block, Hotel Equatorial Shanghai \\ No.65, Yan An Road (West), Shanghai, 200040, China \\ 中国上海市延安西路65号上海国际贵都大饭店办公楼405单元 \\ Phone: +86-21-62489820 \\ Fax: $+86-21-62489821$
}


(C) 2012 The Author(s). Licensee IntechOpen. This is an open access article distributed under the terms of the Creative Commons Attribution 3.0 License, which permits unrestricted use, distribution, and reproduction in any medium, provided the original work is properly cited. 